\title{
Effects of medetomidine/ketamine and xylazine/ketamine anesthesia and their reversal by atipamezole on ocular parameters and monitored anesthesia care in cats
}

\author{
Murat KİBAR $^{1, a, \otimes}$, Abdülkadir KESKİN ${ }^{2, b}$, Ayperi AYTMİRZAKIZI ${ }^{3, c}$, Zeynep ÖZTÜRK $^{4, d}$ \\ ${ }^{1}$ Artvin University, Artvin Vocational School, Hunting and Wild Life Medicine Programme, Artvin, Turkey; ${ }^{2}$ Bursa Uludağ \\ University, Faculty of Veterinary Medicine, Department of Obstetrics and Gynecology, Bursa, Turkey; ${ }^{3}$ Faculty of Veterinary \\ Medicine, Kyrgyzstan Turkish Manas University, Small Animal Clinic, Bishkek, Kyrgyzstan; ${ }^{4}$ Artvin University, Hopa Faculty of \\ Economics and Administrative Sciences, Department of Business, Artvin, Turkey \\ aORCID: 0000-0001- 8879-4121; ' $\mathrm{O}$ ORCID: 0000-0001-7149-0009; ' ORCID: 000000033363 0941; dORCID: 0000-0002-5165-0877
}

Corresponding author: muratkibar@artvin.edu.tr

Received date: 28.01.2021 - Accepted date: 08.07.2021

\begin{abstract}
The aim of this study was to investigate the impact of the general anesthetic drug ketamine and premedication agents medetomidine and xylazine, and their reversal by atipamezole, on monitored anesthesia care values and ocular parameters such as intraocular pressure, horizontal pupillar diameter, and Schirmer tear test in cats. A randomized, single-blinded study was conducted. Twenty intact female cats (weiging between 2.2 and $3.6 \mathrm{~kg}$, and 0.5 to 5.5 years of age) referred for ovariohysterectomy (OHE) procedure by the owners at regular intervals over 4 months were included in the study. The cats were randomly divided into two groups containing 10 animals in each group. The cats were premedicated with medetomidine $80 \mu \mathrm{g} / \mathrm{kg}$ intramuscular in group 1 while the cats in the $2^{\text {nd }}$ group were premedicated with xylazine hydrochloride $2 \mathrm{mg} / \mathrm{kg}$ intramuscular. After the OHE procedure was ended, anesthesia regimes were reversed by using atipamezole $200 \mu \mathrm{g} / \mathrm{kg}$ intramuscularly. Monitoring of respiration rate, heart rate, mean arterial pressure, peripheral arterial oxygen saturation, and body temperature were conducted using a patient monitor at T0, T1, T2, T3, and T4 time points. Both groups showed declines in intraocular pressure and increases in horizontal pupil diameter after anesthesia induction (T0 vs. $\mathrm{T} 1$, all, $\mathrm{P}<0.05$ ); however, the chancing and recovery pattern of intraocular pressure and horizontal pupil diameter showed intergroup difference. In conclusion, xylazine/ketamine is more effective than medetomidine/ketamine in attenuating the intraocular pressure, increasing the horizontal pupil diameter, and alteration the monitored anesthesia care response in the general anesthesia.
\end{abstract}

Keywords: Anesthesia, atipamezole, cat, ocular.

\section{Kedilerde medetomidin/ketamin ve ksilazin/ketamin anestezisinin ve bunların atipamezol ile etkilerinin ters çevrilmesinin oküler ve anestezi izlem parametreleri üzerindeki etkileri}

Özet: Bu çalışmanın amacı, genel anestezik ilaç ketamin ve premedikasyon ilaçları medetomidin ve ksilazinin; ve bunların etkilerinin atipamezol ile tersine çevrilmesinin göz içi basınc1, yatay pupil çapı ve Schirmer gözyaşı testi gibi kedi oküler ve anestezi izlem parametreleri üzerindeki etkilerini araştırmaktı. Rastlantısal, tek tarflı kör bir çalışma yürütüldü. Sahipleri tarafından 4 aylık süre içerisinde ovaryohisterektomi operasyonu için başvurulan 20 erişkin dişi kedi (2,2 ila 3,6 kg ve 0,5 ila 5,5 yaş arasında) çalışmaya dahil edildi. Kediler, her grupta on kedinin olduğu iki gruptan birine rastlantısal olarak dahil edildi. Grup 1'de kediler kas içi $80 \mu \mathrm{g} / \mathrm{kg}$ medetomidin ile premedike edilirken grup 2 deki kediler kas içi ksilazin hidroklorür $2 \mathrm{mg} / \mathrm{kg}$ ile premedike edildi. Ovariohisterektomi işlemi bittikten sonra anestezik etki kasiçi atipamezol $200 \mu \mathrm{g} / \mathrm{kg}$ kullanılarak ters çevrildi. Solunum sayısı, kalp atım hızı, ortalama arter kan basınc1, periferik arteriyel oksijen düzeyi ve vücut ısının izlenmesi T0, T1, T2, T3 ve T4 zaman noktalarında hastabaşı monitör kullanılarak gerçekleştirildi. Her iki grup da anestezi indüksiyonundan sonra istatistiki olarak önemli olan göz içi basıncında düşüş ve yatay pupil çapında artış gösterdi ( $\mathrm{T} 0$ 'a karşı $\mathrm{T} 1$, tümü, $\mathrm{P}<0,05$ ); bununla birlikte, göz içi basıncı ve yatay pupil çapının anestezideki değişim ve başlangıç değerine dönüşler gruplar arası farklıydı. Sonuç olarak ksilazin/ketamin kombinasyonu, genel anestezide göz içi basıncını azaltmada, yatay pupil çapını artırmada ve izlenen anestezi bakım parametrelerini değiştirmede medetomidin/ketamin kombinasyonundan daha etkilidir.

Anahtar sözcükler: Anestezi, atipamezol, kedi, oküler. 


\section{Introduction}

Anesthesia drugs and endotracheal intubation have vitally significant effects on the cardiovascular and pulmonary systems. At the same time, they cause sudden increases in intraocular pressure. This leads to severe complications occurring in surgical interventions performed on patients, in particular, those with ocular trauma or glaucoma $(4,18,19,23,24,37,45)$.

Increasing intraocular pressure (IOP) in ophthalmic surgery has always been problematic for the surgeon and it is necessary to prevent the elevation of $\operatorname{IOP}(2,32)$. Anesthesia for a patient with a penetrating eye injury and a full stomach is a challenge to the anesthesiologist. In these cases the aim of anesthesia is rapid sequence induction without increasing IOP. The anesthesiologist must plan carrefully the risk of aspiration against the risk of blindness in the injured eye that could result from elevated IOP and extrusion of ocular contents (2).

Monitored anesthesia care (MACr) has been utilized to ensure relief from anxiety, sedation, minimal memory loss, and comfort throughout diagnostic or therapeutic applications with analgesia and sedation $(15,26)$. Respiratory decrease is associated with the most significant case injuries in $\operatorname{MACr}(16,26)$. The goal of $\mathrm{MACr}$ is the management of anesthesia and maintenance of optimal cardiac functions without intense respiratory down and airway obstruction. The ability to quickly modulate the depth of anesthesia when needed is also a significant aspect of MACr. Several narcotics, analgesics and sedatives are utilized to obtain these aims while minimizing side effects (26).

Anesthesia with the combination of medetomidine/ ketamine (MED-KET) and xylazine/ketamine (XYZKET), each of which can be antagonized by atipamezole, has been described as a useful anesthetic technique for animals $(1,6,31)$. Obvious benefits of these drug combinations are related to the competitive reversibility by atipamezole for all components, which leads to improved control of anesthetic depth, a shorter recovery phase and lower occurance of hypothermia $(1,23,31)$.

While there has been extensive research on some general anesthesia and premedication agent pharmacodynamics and pharmacokinetics, information on their impact on MACr and ocular parameters, such as IOP, horizontal pupil diameter (HPD), and Schirmer's tear test (STT) in animals and particularly cats, are few, deficient and rather contentious $(6,26)$. To our knowledge, no articles have focused on the impact of medetomidine/ ketamine and xylazine/ketamine anesthesia on ocular parameters and MACr values in cats. The aim of this study was to investigate the impact of the general anesthetic drug ketamine and premedication agents medetomidine and xylazine, and their reversal by atipamezole, on monitored anesthesia care values and ocular parameters such as intraocular pressure, horizontal pupillar diameter, and Schirmer tear test in cats.

\section{Materials and Methods}

The experimental procedure was authorized by the Local Ethics Committee of Kyrgyz Turkish Manas University (Approval Number: 2016-03/2). A randomized, single-blinded study was conducted.

Sampling: Twenty intact female cats (weighing between 2.2 and $3.6 \mathrm{~kg}$, and 0.5 to 5.5 years of age) referred for ovariohysterectomy $(\mathrm{OVH})$ procedure by owner at regular intervals over 4 months were included in the study.

Experimental procedure: The cats were randomly divided into two groups containing 10 animals in each group (T0, baseline). Carprofen (Rimadyl ${ }^{\circledR}$, Zoetis, USA) $2 \mathrm{mg} / \mathrm{kg}$ IV was applied to all cats for analgesia. The cats were anesthesied using a combine with medetomidine (Tomidine $^{\circledR}$, Provet, Turkey) $80 \mu \mathrm{g} / \mathrm{kg}$ IM and ketamine hydrochloride (Alfamin ${ }^{\circledR}$, Egevet, Turkey) $10 \mathrm{mg} / \mathrm{kg}$ IM in group 1 (T1: after 10 min combined anesthesia). Similarly, cats were anesthesied using a combine with xylazine hydrochloride (Alfazin ${ }^{\circledR}$, Egevet, Turkey) $2 \mathrm{mg} / \mathrm{kg}$ IM and ketamine hydrochloride (Alfamin ${ }^{\circledR}$, Egevet, Turkey) $10 \mathrm{mg} / \mathrm{kg}$ IM group 2. Electrocardiogram, oscillometric mean arterial blood pressure (MAP), respiratory rate $(\mathrm{RR})$, heart rate $(\mathrm{HR})$, hemoglobin oxygen saturation $\left(\mathrm{SpO}_{2}\right)$, and rectal body temperature $(\mathrm{BT})$ were monitored by multiparameter monitor (G9000, Guoteng, China) with $5 \mathrm{~min}$ intervals throughout the anesthesia (T2: after 15 min starting operation; T3: after last suture). After the OHE procedure was ended, anesthesia regimes were reversed by using atipamezole (Reversal ${ }^{\circledR}$, Provet, Turkey) $200 \mu \mathrm{g} / \mathrm{kg}$ (T4: after $10 \mathrm{~min}$ reversed) IM.

Animals breathed spontaneously during anesthesia and were not intubated in order to avoide a heightened effect on the IOP. Monitoring of heart rate, RR, MAP, $\mathrm{SpO}_{2}$, and $\mathrm{BT}$ was conducted using a patient monitor at T0, T1, T2, T3, and T4 time points. Clinical data, including RR, HR, MAP, $\mathrm{SpO}_{2}$, and $\mathrm{BT}$ were recorded concurrently.

Ocular exams: Ocular parameters were measured at T0, T1, T2, T3, and T4 time points. All ocular measurements were performed with the cat with the care taken not to occlude the jugular veins or place pressure on the globe while retracting the eyelids. The cats were in dorsal recumbency in $\mathrm{T} 3$ time point, and in lateral recumbency at other time points. One researcher who was blind to the anesthetic drug, performed all IOP controls using a rebound tonometry (Tonovet, Tiolat, Finland). Intraocular pressure was evaluated on the center of the cornea in accordance with the instruction manual of each tonometer. The tonometer was factory-calibrated before 
the study and calibrated each day before data collection. Three readings were obtained in the right eye at each measurement time. The mean of the three readings was recorded. No local anesthetic drop was used before IOP measurement. PS was measured with a caliper horizontally at the same time points. Schirmer tear test I was performed using commercial Schirmer strips placed in the lower fornix for $1 \mathrm{~min}$.

Ovariohysterectomy was carried out in cats after T1 time point. All surgeries were performed by the same gynecolog with assisstance from veterinary students. All cats were discharged 24 hours after the operation.

Statistical analysis: Mean \pm SE values were used to estimate the values of all data. Statistical analysis was performed using nonparametric tests since the sample size was small and the data were not normally distributed. In order to test whether the effects of the drug differed from the median values, the Friedman test was used to analyze the variables between the two groups. Comparisons between the groups were made employing the MannWhitney $U$ test, and differences between measurements were taken over time using the Wilcoxon test. Statistical significance was set at a probability value of $\mathrm{P}<0.05$ with a two-sided confidence interval and assumption of equal variance. The statistical analyses were run using SPSS statistical programme (22.0, IBM Company, USA).

\section{Results}

No statistically significant differences were observed between the treatment groups with regard to body weight (BW), body condition score (BCS), age and baseline measurements of $\mathrm{HR}, \mathrm{RR}, \mathrm{SpO}_{2}$, and $\mathrm{BT}$. All of baseline monitoring values were within the expected reference ranges for anesthetized cats (Table 1).

Table 1. Animal data and baseline (T0) physiological variables for both groups, Mean $( \pm \mathrm{SE})$.

\begin{tabular}{llll}
\hline Patient variable & MED-KET & XYZ-KET & P \\
$\mathrm{BW} \mathrm{(kg)}$ & $2.66 \pm 0.13$ & $2.80 \pm 0.99$ & 0.223 \\
$\mathrm{BCS}$ & $2.78 \pm 0.15$ & $3.00 \pm 0.0$ & 0.072 \\
Age (years) & $1.43 \pm 0.20$ & $2.10 \pm 0.53$ & 0.067 \\
$\begin{array}{l}\text { Baseline HR } \\
\text { (beats/min) }\end{array}$ & $173.82 \pm 13.40$ & $177.00 \pm 13.99$ & 0.677 \\
$\begin{array}{l}\text { Baseline RR } \\
\text { (breaths/min) }\end{array}$ & $11.56 \pm 0.54$ & $12.00 \pm 0.56$ & 0.939 \\
$\begin{array}{l}\text { Baseline SPO } \\
\text { Baseline BT (C) }\end{array}$ & $91.20 \pm 0.75$ & $91.10 \pm 0.35$ & 0.726 \\
\hline
\end{tabular}

BW: body weight, BCS: body condition score, HR: heart rate, RR: respiratory rate, $\mathrm{SpO}_{2}$ : hemoglobin oxygen saturation, and BT: rectal body temperature, NS ( $\mathrm{P}>0.05)$.

The serial monitorized data changes in MED-KET and XYZ-KET group are compared in Table 2. Within the MED-KET group, the HR decreased significantly after medetomidine and ketamine injection. There is a statistically significant difference between times $(\mathrm{P}=0.005)$. There was a statistically significant difference at $\mathrm{T} 1, \mathrm{~T} 2$ and $\mathrm{T} 3$ versus at $\mathrm{T} 0(\mathrm{~T} 1, \mathrm{~T} 2, \mathrm{~T} 3$ vs. T0, $\mathrm{P}=0.005$, $\mathrm{P}=0.014$ and $\mathrm{P}=0.005$, respectively); though values were not significanly different from baseline by T4 (T0 vs. T4, $\mathrm{P}=0.508$ ). Even though the HR reduced temporarily, the quartile range was within normal values [T1:103.80 (60.00-148.00), T2: 124.41 (67.00-200.00), T3: 113.50 (68.00-175.00)].

Table 2. The serial monitorized data changes in MED-KET and XYZ-KET group.

\begin{tabular}{|c|c|c|c|c|c|c|c|}
\hline & Group & T0 & $\mathrm{T} 1$ & $\mathrm{~T} 2$ & $\mathrm{~T} 3$ & T4 & $\begin{array}{l}\text { P-within } \\
\text { group }\end{array}$ \\
\hline \multirow{2}{*}{ HR (beats/min) } & MED-KET & $173.82 \pm 13.40$ & $103.80 \pm 9.91^{*}$ & $124.41 \pm 10.72^{*}$ & $113.50 \pm 9.07^{*}$ & $158.80 \pm 21.25$ & \multirow{2}{*}{0.940} \\
\hline & XYZ-KET & $177.00 \pm 13.99$ & $117.00 \pm 11.05^{*}+$ & $98.34 \pm 11.98^{*}+$ & $99.90 \pm 6.05^{*}+$ & $158.25 \pm 14.00$ & \\
\hline \multicolumn{2}{|c|}{ P-within group by time } & 0.677 & 0.473 & 0.211 & 0.344 & 0.821 & \multirow{3}{*}{0.140} \\
\hline \multirow{2}{*}{$\mathrm{SPO}_{2}(\%)$} & MED-KET & $91.20 \pm 0.75$ & $87.80 \pm 2.24$ & $89.07 \pm 2.15$ & $88.60 \pm 2.63$ & $87.40 \pm 2.14$ & \\
\hline & XYZ-KET & $91.10 \pm 0.35$ & $89.70 \pm 1.16$ & $90.30 \pm 2.07$ & $91.10 \pm 1.83$ & $91.80 \pm 0.66$ & \\
\hline \multicolumn{2}{|c|}{ P- within group by time } & 0.726 & 0.761 & 0.495 & 0.545 & 0.129 & \multirow{3}{*}{0.120} \\
\hline \multirow{2}{*}{ RR (breaths/min) } & MED-KET & $11.56 \pm 0.54$ & $12.70 \pm 0.83$ & $12.04 \pm 0.81$ & $12.20 \pm 0.85$ & $12.60 \pm 0.90$ & \\
\hline & XYZ-KET & $12.00 \pm 0.56$ & $11.20 \pm 0.77$ & $10.84 \pm 0.47$ & $12.70 \pm 1.13$ & $11.08 \pm 0.64$ & \\
\hline \multicolumn{2}{|c|}{ P- within group by time } & 0.939 & 0.237 & 0.236 & 0.818 & 0.293 & \multirow{3}{*}{0.031} \\
\hline \multirow{2}{*}{ MAP (mmHg) } & MED-KET & $108.50 \pm 4.96$ & $104.00 \pm 3.33$ & $113.82 \pm 4.98$ & $117.90 \pm 3.84$ & $110.72 \pm 7.38$ & \\
\hline & XYZ-KET & $101.50 \pm 5.11$ & $94.00 \pm 7.76$ & $99.65 \pm 10.97$ & $108.70 \pm 6.02$ & $102.48 \pm 8.03$ & \\
\hline \multicolumn{2}{|c|}{ P- within group by time } & 0.040 & 0.344 & 0.402 & 0.289 & 0.253 & \multirow{3}{*}{0.364} \\
\hline \multirow{2}{*}{$\mathrm{BT}\left({ }^{0} \mathrm{C}\right)$} & MED-KET & $38.77 \pm 0.14$ & $38.23 \pm 0.33$ & $36.62 \pm 0.36^{*}, \dagger, \dagger$ & $34.83 \pm 0.37^{*}, \dagger$ & $34.60 \pm 0.47^{*}, \uparrow$ & \\
\hline & XYZ-KET & $38.59 \pm 0.23$ & $38.06 \pm 0.39$ & $35.74 \pm 0.30^{*}, \dagger$ & $34.40 \pm 0.51^{*, \dagger}$ & $34.73 \pm 0.39^{*}, \dagger$ & \\
\hline \multicolumn{2}{|c|}{ P- within group by time } & 0.663 & 0.850 & 0.043 & 0.529 & 0.570 & \\
\hline
\end{tabular}


Within the XYZ-KET group, the HR decreased significantly after xylazine and ketamine injection. There is a statistically significant difference between times $(\mathrm{P}=0.005)$. There was a statistically significant difference at T1, T2 and T3 versus at T0 (T1, T2, T3 vs. T0, $\mathrm{P}=0.005$, $\mathrm{P}=0.014$ and $\mathrm{P}=0.005$, respectively); though values were not significanly different from baseline by T4 (T0 vs. T4, $\mathrm{P}=0.508)$. Even though the HR reduced temporarily, the quartile range was within normal values [T1: 117.00 (53157), T2: 98.34 (32-160), T3: 99.90 (73-130)].

Comparison of the impact on monitorized changes data between MED-KET and XYZ-KET group is presented in Table 2. The HR values comparison between groups is illustrated in Figure 1. It is seen from the p values in the Table 2 that the monitorizing change data between the MED-KET and XYZ-KET groups were not statistically significant different over time.

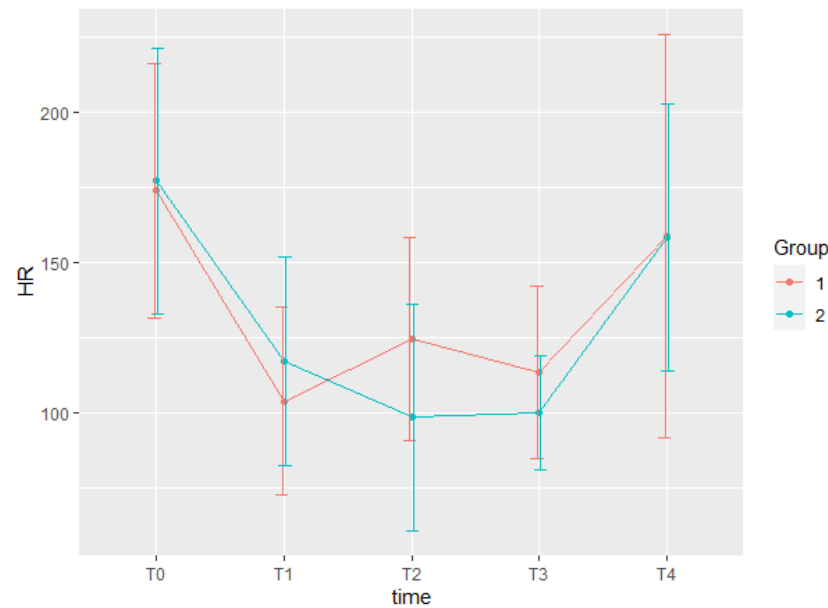

Figure 1. Comparison of HR values between MED-KET and XYZ-KET group.

The serial intraocular parameter changes in MEDKET and XYZ-KET group are compared in Table 3. Within the MED-KET group, the STT reduced significantly after medetomidine and ketamine injection.
There is a statistically significant difference between times $(\mathrm{P}<0.001)$. There was a statistically significant difference at $\mathrm{T} 1, \mathrm{~T} 2$ and $\mathrm{T} 3$ versus at $\mathrm{T} 0$ (T1, T2, T3 vs. T0, $\mathrm{P}=0.005$, $\mathrm{P}=0.005$ and $\mathrm{P}=0.007$, respectively); though values were not significanly different from baseline by T4 (T0 vs. T4, $\mathrm{P}=0.233$ ). Even though the STT decreased temporarily, the quartile range was within normal values [T1: 5.50 (2.00-15.00), T2:4.20 (3.00-13.00), T3:4.40 (2.00-8.00)].

Within the XYZ-KET group, the STT reduced significantly after xylazine and ketamine injection. There is a statistically significant difference between times $(\mathrm{P}=0.005)$. There was a statistically significant difference at $\mathrm{T} 2$ and $\mathrm{T} 3$ versus at $\mathrm{T} 0$ (T2, T3 vs. T0, $\mathrm{P}=0.035$ and $\mathrm{P}=0.050$, respectively); though values were not significanly different from baseline by T4 (T0 vs. T4, $\mathrm{P}=0.779$ ). Even though the STT decreased temporarily, the quartile range was within normal values [T2: 6.54 (313), T3: 6.50 (2-13)].

Comparison of the impact on intraocular paramaters between MED-KET and XYZ-KET group is presented in Table 3. Both groups showed declines in IOP and increases in HPD after anesthesia induction (T0 vs. T1, all, $\mathrm{P}<0.05$ ); however, the changing and recovery pattern of IOP and HPD showed intergroup difference. In IOP, the baseline value was similar between the two $(\mathrm{P}=0.939)$, with the first drop at $\mathrm{T} 1$ and $\mathrm{T} 2(\mathrm{P}=0.790, \mathrm{P}=0.705$, respectively), however, after that point the MED-KET group showed more recovery and a higer level of IOP compared with those in the XYZ-KET group [T3: 23.60 (19.00-37.00) vs. 18.30 (9.00-33.00), $\mathrm{P}=0.019]$ (Table 3). In HPD, the baseline value was similar between the two $(\mathrm{P}=0.234)$. After that point the XYZ-KET group showed more recovery and a higher level of IOP compared with those in the MED-KET group [T1: 9.10 (7.00-11.00) vs. 7.10 (5.00-10.00), $\mathrm{P}=0.022$; T2: 8.27 (5.00-10.00) vs. 7.10 (5.00-9.00), $\mathrm{P}=0.037$; T3: 8.50 (7.00-10.00) vs. 6.90 (5.00-9.00), $\mathrm{P}=0.013$ (Table 3).

Table 3. The serial intraocular parameter changes in MED-KET and XYZ-KET.

\begin{tabular}{|c|c|c|c|c|c|c|c|}
\hline & Group & T0 & $\mathrm{T} 1$ & $\mathrm{~T} 2$ & $\mathrm{~T} 3$ & $\mathrm{~T} 4$ & P-within group \\
\hline \multirow{2}{*}{ IOP } & MED-KET & $24.52 \pm 2.85$ & $22.60 \pm 2.88$ & $20.90 \pm 2.16$ & $23.60 \pm 1.79$ & $23.20 \pm 2.45$ & \multirow{2}{*}{0.762} \\
\hline & XYZ-KET & $22.70 \pm 1.30$ & $21.90 \pm 1.23$ & $19.70 \pm 1.31$ & $18.30 \pm 2.06$ & $24.69 \pm 2.79$ & \\
\hline \multicolumn{2}{|c|}{ P- within group by time } & 0,939 & 0.790 & 0.705 & 0.019 & 0.910 & \multirow{3}{*}{0.034} \\
\hline \multirow{2}{*}{ PS } & MED-KET & $6.60 \pm 0.40$ & $7.10 \pm 0.57$ & $7.10 \pm 0.38$ & $6.90 \pm 0.43$ & $7.40 \pm 0.40$ & \\
\hline & XYZ-KET & $6.40 \pm 0.40$ & $9.10 \pm 0.46$ & $8.27 \pm 0.43$ & $8.50 \pm 0.34$ & $8.39 \pm 0.43$ & \\
\hline \multicolumn{2}{|c|}{ P- within group by time } & 0.234 & 0.022 & $\mathbf{0 . 0 3 7}$ & 0.013 & 0.113 & \multirow{3}{*}{0.325} \\
\hline \multirow{2}{*}{ STT } & MED-KET & $12.84 \pm 1.59$ & $5.50 \pm 1.23^{*}+$ & $4.20 \pm 0.59^{*}+$ & $4.40 \pm 0.56^{*}+$ & $10.00 \pm 1.67$ & \\
\hline & XYZ-KET & $9.94 \pm 1.02$ & $8.10 \pm 1.35$ & $6.54 \pm 1.05^{*}+\dagger$ & $6.50 \pm 1.18^{*, \dagger} \dagger$ & $10.74 \pm 0.79$ & \\
\hline \multicolumn{2}{|c|}{ P- within group by time } & 0.270 & 0.085 & 0.064 & 0.171 & 0.379 & \\
\hline
\end{tabular}

${ }^{*} \mathrm{P}<0.05$ : vs. T0 within the group, ${ }^{\dagger} \mathrm{P}<0.05$ : vs. $\mathrm{T} 1$ within the group, $\$ \mathrm{P}<0.05$ : vs. $\mathrm{T} 4$ within the group, IOP: Intraocular pressure, PS: pupil size, STT: Schirmer tear test. 


\section{Discussion and Conclusion}

For ophthalmic surgery, to improve technique in general anesthesia, fixed cardiac parameters and intraocular pressure should be significant considerations $(7,10,29)$. Some premedication agents and general anesthetics reduce IOP and decrease the HPD due to miosis. Ketamine, however, raises the IOP and causes enlargement of the pupilla in human subjects $(12,20,29$, 42).

Intraocular ophthalmic surgery in veterinary medicine has seen significant development over the last decades $(13,14,28)$. Insufficient management of anesthesia can cause poor vision when the eyelids are unlocked throughout operation. The coaction of ophthalmic agents with premedicant agents must be considered prior to administration of anesthesia. Furthermore, as premedicants may have specific impacts on the physiology of the eye, this must be kept in mind for researchers overseeing anesthesia for ocular surgery. This is of extreme importance if requirements, such as immobility, decreased oculocardiac reflex, fixed eye, decreased intraocular pressure, minimal bleeding, smooth emergence without retching, nausea, or vomiting and postoperative analgesia are to be met for reliable ocular surgery $(28,35)$. Moreover, decrease in IOP and stabil bulbus oculi are preliminary conditions for smooth surgery and intraocular operation procedures $(28,35)$. The management of IOP is frequently of preliminary importance in intraocular operations. Premedicants that affect IOP have a determinative role in ensuring smooth surgery $(5,28,38)$.

One of the problematic intraocular surgery operations for the surgeon is increasing IOP, so elevation of IOP and maintaining it within normal range is necessary $(17,33)$. IOP control before, during, and after the surgery is required for anesthesia management in ophthalmic surgery and one important aim in anesthetic management during ocular surgery is to provide adequate control of $\operatorname{IOP}(17,43)$.

Strategies for induction of anesthesia are known to affect IOP in people $(1,23,31)$. Abrupt increases in IOP in patients with near-perforating corneal trauma or glaucoma can cause dramatic effects. Prolapse of ocular contents complicates the surgical procedure and worsens the prognosis for recovery $(9,23)$. In animals with glaucoma, even minimal increases in IOP can lower axoplasmic flow within the optic nerve, predisposing to further injury $(23,44)$. Hence, any method that prevents elevation in IOP during induction of anesthesia may be of benefit in patients with ocular trauma or glaucoma and in those undergoing anesthesia for intraocular surgery.

One aim of managing of anesthesia throughout intraocular operation is to ensure a normotensive level of IOP. A rise in IOP may be disastrous in cases with glaucoma or a penetrating injury of the bulbus oculi. The IOP is determined by the incidence of vitreous capacity and manufacture of aqueous humour, external pressure, orbicularis oculi muscle tension and scleral rigidity (11, 27, 40). The ordinary IOP is around $15 \mathrm{~mm} \mathrm{Hg}$, with an accaptable value of $10 \pm 20 \mathrm{~mm} \mathrm{Hg}$. Former investigations have evaluated the impacts of premedicants and anesthetics, and related agents on IOP, though underlying factors impacting IOP are unclear.

Ocular and visual function may be impaired postoperatively if there are large variations in IOP in open-system ocular surgery. Mechanical and pharmacological stress during surgery must be avoided because these procedures can contribute to an increase in IOP $(3,30,33)$. In general anesthesia in ocular surgery, short-acting anesthetic agents are commonly used. The central depressive effect on the diencephalic control of IOP, relaxing extraocular muscle tone and improving the aqueous humour outflow causes a reduction in IOP with the use of most anesthetics $(21,33,34)$. It is shown that some agents, such as propofol, thiopental, halothane, isoflurane and desflurane, fentanyl, alfentanil and remifentanil decrease IOP $(8,18,33,34)$.

Research of normotensive dogs and rabbits has noted that medetomidine reduces the IOP following its local administration to the bulbus oculi $(25,36,42)$. Peripheral $\alpha-2$ receptors in the bulbus oculi, both prejunctionally on bulbar sympathetic nerves and postjunctionally, are likely related in the physiological arrangement of IOP. This arrangement is obtained by lowing the alerted manufacture of cyclic AMP in the ciliary process $(25,36$, 42).

Regarding the impacts of ketamine on intraocular pressure, a signifcant rise in IOP has been achieved in dogs. In a similar study with dogs, a dose of $10 \mathrm{mg} / \mathrm{kg}$ of ketamine in combination with xylazine or acepromazine was applied, but increase in IOP was not achieved (29). The effect of intravenous ketamine administration alone on the IOP in dogs was studied and a significant increase after 5 and 10 minutes at $5 \mathrm{mg} / \mathrm{kg}$ dose was determined $(22,25,39,41)$.

In conclusion, XYZ-KET is more effective than MED-KET in attenuating the IOP, increasing the HPD, and alteration of the MACr response in general anesthesia. This temporary reduction in IOP could likely be helpful in eye operations especially in animals with high IOP values. Additionally, dilated HPD could possibly aid in the avoidance of anretior sinechia during corneal surgery. Future investigations may focus on the impact of other premedicant or induction agents on the IOP, HPD, and $\mathrm{MACr}$ to confirm our results for medetomidine and xylazine, and on evaluating the effects on the IOP, HPD, and $\mathrm{MACr}$ of different doses of medetomidine or xylazine. 


\section{Acknowledgements}

Some part of this article was summarized from the first author's master thesis.

\section{Financial Support}

This research received no grant from any funding agency/sector.

\section{Ethical Statement}

This study was approved by the Local Ethics Committee of Turkish Manas University (Approval Number: 2016-03/2).

\section{Conflict of Interest}

The authors are declared that there is no conflict of interest.

\section{References}

1. Badrinath SK, Vazeery A, McCarthy RJ, et al (1986): The effect of different methods of inducing anesthesia on intraocular pressure. Anesthesiol, 65, 431-435.

2. Banga PK, Singh DK, Dadu S, et al (2015): A comparative evaluation of the effect of intravenous dexmedetomidine and clonidine on intraocular pressure after suxamethonium and intubation. Saudi J Anesth, 9, 179-183.

3. Bathija R, Gupta N, Zangwill L, et al (1998): Changing definition of glaucoma. J Glaucoma, 7, 165-169.

4. Batista CM, Laus JL, Nunes N, et al (2000): Evaluation of intraocular and partial $\mathrm{CO}_{2}$ pressure in dogs anesthetized with propofol. Vet Ophthal, 3, 17-19.

5. Benson GJ, Manning JP, Hartsfield SM, et al (1998): Intraocular Tension of the Horse. Effects of Succinylcholine and Halothane Anesthesia. Am J Vet Res, 42, 1831-1832.

6. Bruniges N, Taylor PM, Yates D (2016): Injectable anaesthesia for adult cat and kitten castration: effects of medetomidine, dexmedetomidine and atipamezole on recovery. J Fel Med Surg, 18, 860-867.

7. Brunson DB (1980): Anesthesia in ophtalmic surgery. Vet Clin North Am Small Anim Pract, 10, 481-495.

8. Butterworth JF, Mackey DC, Wasnick JD (2013): Anesthesia for Ophthalmic Surgery. 759-771. In: JF Butterworth, DC Mackey, JD Wasnick (Eds), Morgan and Mikhail's Clinical Anesthesiology. McGraw-Hill Professional, New York.

9. Chmielewski NT, Brooks DE, Smith PJ, et al (1997): Visual outcome and oular survival after iris prolapse in the horse: a review of 32 cases. Equine Vet J, 29, 31-39.

10. Collins BK, Gress ME, Moore CP, et al (1997): Physiologic, pharmacologic, and practical considerations for anesthesia of domestic animals with eye disease. $\mathrm{J}$ Am Vet Med Assoc, 207, 220-230.

11. Cunningham AJ, Barry P (1986): Intraocular pressure physiology and implications for anaesthetic management. Can Anaesth Soc J, 33, 195-208.

12. Frischmeyer KJ, Miller PE, Bellay Y, et al (1993): Parenthal anticholinergics in dogs with normal and elevated intraocular pressure. Vet Surg, 23, 230-234.
13. Gelat KN (1991): Veterinary Ophthalmology. Lea \& Fibiger, Philadelphia.

14. Gelat KN (2000): Essentials of Veterinary Ophthalmology. Lippincott, Philadelphia.

15. Gelatt KN, Brooks DE, Kallberg ME (2007): The Canine Glaucomas. 762-780. In: KN Gellatt (Ed), Veterinary Ophthalmology. Blackwell Publishing, Florida. 762.

16. Gellatt KN, Gwin R, Peiffer RL, et al (1977): Tonography in normal and glaucomatous beagle. Am J Vet Res, 38, 515520.

17. Goepfert CE, Ifune C, Tempelhoff $\mathbf{R}$ (2010): Ischemic optic neuropathy: are we any further? Curr Opin Anaesth, 23, 582-587.

18. Grosso A, Scozzari G, Bert F, et al (2013): Intraocular pressure variation during colorectal laparoscopic surgery: Standard pneumoperitoneum leads to reversible elevation in intraocular pressure. Surg Endosc, 27, 3370-3376.

19. Güzel Ö, Erdikmen DO, Yıldar E, et al (2013): The effects of propofol and a diazepam/alfentanil combination in dogs aged 10 years and above on heart rate, respiratory rate, pulse oximetry data, intraocular pressure, and body temperature. Turk J Vet Anim Sci, 37, 170-176.

20. Hahnenberger RW (1976): Influence of various anesthetic drugs on intraocular pressure in cats. Alb. Won Graefes Arc Klin Exp Ophtalmol, 199, 179-186.

21. He Z, Vingrys AJ, Armitage JA, et al (2011): The role of blood pressure in glaucoma. Clin Exp Optom, 94, 133-149.

22. Hofmeister EH, Mosunic CB, Torres BT, et al (2002): Effects of ketamine, diazepam and their combination of intraocular pressures in clinically normal dogs. Am J Vet Res, 67, 1136-1139.

23. Hofmeister EH, Williams CO, Braun C, et al (2006): Influence of lidocaine and diazepam on peri-induction intraocular pressures in dogs anesthetized with propofolatracurium. Can J Vet Res, 26, 51-56.

24. Hofmeister H, Weinstein WL, Burger D, et al (2009): Effects of graded doses of propofol for anesthesia induction on cardiovascular parameters and intraocular pressures in normal dogs. Vet Anaesth Analg, 36, 442-448.

25. Jin Y, Wilson S, Elko EE, et al (1991): Ocular hypotensive effects of medetomidine and its analogs. J Ocul Pharmacol, 7, 285-296.

26. Karabağlı M, Özer K, Şahin I (2014): The effects of xylazine-ketamine anesthesia on intraocular pressure in dogs. J Fac Vet Med Istanbul Univ, 40, 260-263.

27. Katzenschlager SS, Deusch E, Dolezal S, et al (2002): Sevoflurane and propofol decrease intraocular pressure equally during non-ophthalmic surgery and recovery. British J Anaesth, 89, 764-766.

28. Kılıç S, Ünsaldı S (2009): Effects of isoflurane and snflurane on ocular parameters in dogs. YYU J Fac Vet Med, 20, 1-3.

29. Kovalcuka L, Birgele E (2011): The effects of some premedication and general anesthesia drugs on intraocular pressure and pupil diameter in Dog's eyes. LLU Raksti, 26, $77-83$.

30. Kymes SM, Kass MA, Anderson DR, et al (2006): Ocular Hypertension Treatment Study Group (OHTS). Management of ocular hypertension: a cost-effectiveness approach from the ocular hypertension treatment study. Am J Ophthalmol, 141, 997-1008. 
31. Lev R, Rosen P (1994): Prophylactic lidocaine use preintubation: a review. J Emerg Med, 12, 499-506.

32. Miller RD (2005): Miller's Anesthesia. Churchill Livingstone, USA.

33. Montazeri K, Dehghan A, Akbari S (2015): Increase in intraocular pressure is less with propofol and remifentanil than isoflurane with remifentanil during cataract surgery: A randomized controlled trial. Adv Biomed Res, 4, 55.

34. Moore D, Harris A, Wudunn D, et al (2008): Dysfunctional regulation of ocular blood flow: a risk factor for glaucoma? Clin Ophthalmol, 2, 849-861.

35. Orkin FK, Cooperman LH (1983): Complications in Anesthesiology. Lippincott, Philadelphia.

36. Ogidigben MJ, Potter DE (1993): Comparative effects of alpha-2 and DA-2 agonists on intraocular pressure in pigmented and nonpigmented rabbits. J Ocul Pharmacol, 9, 187-199.

37. Perk EC, Güzel Ö, Gülanber EG (2002): Etomidate/alfentanil anaesthesia in dogs and its effects on pulse oxymeter, electrocardiography and haematological parameters. Turk J Vet Anim Sci, 26, 1021-1024.

38. Presbitero JV, Ruiz RS, Rigor BM, et al (1980): Intraocular pressure during enflorane and neurolept anesthesia in adult patients undergoing ophthalmic surgery. Anesth Analg, 59, 50-54.

39. Pierce-Tomlin T, Shaughnessy MR, Hofmeister EH (2020): A systematic review of the effects of injectable sedative and anesthetic drugs and inhalant anesthetics on intraocular pressure in the dog. Vet Anaesth Analg, 47, 145-151.

40. Sator S, Wildling E, Schabernig C, et al (1998): Desflurane maintains intraocular pressure at an equivalent level to isoflurane and propofol during unstressed nonophtalmic surgery. British J Anaesth, 80, 243-244.

41. Smith MD, Barletta M, Diehl KA, et al (2019): Effect of propofol and ketamine-diazepam on intraocular pressure in healthy premedicated dogs. Vet Anaesth Analg, 46, 36-42.

42. Verbruggen AMJ, Akkerdaas LC, Hellebrekers LJ (2000): Effects of intravenous medetomidine on pupil size and intraocular pressure in normotensive dog. Vet Quarter, 22, 179-180.

43. Weber ED, Colyer MH, Lesser RL, et al (2007): Posterior ischemic optic neuropathy after minimally invasive prostatectomy. J Neuroophthalmol, 27, 285-287.

44. Williams LW, Gelatt KN, Gum GG, et al (1983): Orthograde rapid axoplasmic transport and ultrastructural changes of the optic nerve. Part 1. Normotensive and acute ocular hypertensive beagles. Glaucoma, 5, 117-128.

45. Zimmerman AA, Funk KJ, Tidwell JL (1996): Propofol and alfentanil prevent the increase in intraocular pressure caused by succinylcholine and endotracheal intubation during a rapid sequence induction of anesthesia. Vet Anaesth Analg, 83, 814-817. 